\title{
Fluorescence commutation and surface photopatterning with porphyrin tetra-dithienylethene switches
}

\author{
Thomas Biellmann, ${ }^{[a]}$ Agostino Galanti, ${ }^{[b]}$ Julien Boixel, ${ }^{[c]}$ Jennifer A. Wytko, ${ }^{[a]}$ Véronique Guerchais ${ }^{*[c]}$ Paolo \\ Samorì ${ }^{\star[b]}$ and Jean Weiss ${ }^{*[a]}$
}

\begin{abstract}
Four tetra-dithienylethene (DTE) substituted porphyrins, the free base $\mathbf{1 H}_{2}$ and three metal derivatives (1Zn, $1 \mathrm{Co}, \mathbf{1 N i}$ ), were synthesized and studied. These dyads, in which the DTE units are connected to the porphyrin's meso positions via a meta-phenyl spacer exhibit reversible photochromic properties in all cases with conversion to the PSS up to $88 \%$, as confirmed by absorption and NMR spectroscopies. Compounds $\mathbf{1} \mathbf{H}_{\mathbf{2}}$ and $\mathbf{1 Z n}$ are fluorescent in solution and display a red emission. Upon irradiation with UV light to trigger the closing of the DTEs, the fluorescence of both the free base and zinc porphyrin was very efficiently quenched in solution. The reversible, photo-triggered switching of luminescence was retained in a tetra-DTE free base porphyrin-doped polystyrene film, for which photo-patterning was demonstrated by confocal scanning microscopy. The tunable fluorescent properties of this multi-DTE framework render this compound of interest as a photo-rewritable fluorescent ink.
\end{abstract}

\section{Introduction}

Among the known photochromic switches, ${ }^{[1]}$ the dithienylethene (DTE) scaffold is particularly attractive because of its efficient, fast and fatigue-resistant photoisomerization combined with its thermodynamic stability in both the open and closed isomers. ${ }^{[2]}$ Based on these features, the potential of DTEs as components in photo-electronic devices is now well established, ${ }^{[3]}$ as is their capability of controlling a variety of properties when incorporated in molecular architectures. ${ }^{[4-9]}$ By increasing the number of photoswitches in a single component, one could potentially increase the contrast in the photoresponse of the system, rendering such compounds appealing for information storage. ${ }^{[10]}$ A major challenge in the development of novel, functional systems addressable with light stimuli is therefore to integrate as many efficient photoswitchable units as possible in the same molecular backbone. In multi-photochromic systems in general, and more particularly in multi-DTE scaffolds, the photoresponse was found to depend on reciprocal electronic interactions between the DTE

[a] Dr. T. Biellmann, Dr. J. A. Wytko, Dr. J. Weiss Institut de Chimie de Strasbourg UMR 7177 CNRS-Université de Strasbourg

4 rue Blaise Pascal, F-67000 Strasbourg, France E-mail: jweiss@unistra.fr

[b] Mr. A. Galanti, Prof. P. Samori

University of Strasbourg, CNRS, ISIS UMR 7006,

8 allée Gaspard Monge, F-67000 Strasbourg, France

E-mail: samori@unistra.fr

[c] Dr. J. Boixel, Dr. V. Guerchais

Institut des Sciences Chimiques de Rennes UMR 6226 CNRS - Université de Rennes

263 avenue du Général Leclerc, 35042 Rennes Cedex, France

E-mail: veronique.guerchais@univ-rennes1.fr

Supporting information for this article is given via a link at the end of the document. moieties. In many cases, complete closure of the DTEs does not occur because, upon UV irradiation of a scaffold containing both open and closed DTE moieties, intramolecular energy transfer from an open to a closed DTE may prevent additional ring closures. Although exceptionally high closed to open ratios $(>90 \%)$ were reported for di-, ${ }^{[11,12]}$ tri-[12] $^{[12}$ and hexa-DTE ${ }^{[13]}$ arrays, most multi-DTE scaffolds exhibited more modest photoisomerization results. ${ }^{[14-17]}$

Extensive investigations on multi-photochromic molecular systems have helped to elucidate the role of the bridging unit interconnecting the chromophores within the same molecular scaffold. ${ }^{[14]}$ Photochromism inhibition typically results upon conjugation of the photoswitch with an extended aromatic system due to the appearance of a low-lying excited state that does not lead to the desired photoisomerization. Generally, suitable connectors must be chosen to decrease the electronic delocalization over the entire $\pi$-backbone. Although diverse linkers ${ }^{[11,14,17-21]}$ have been incorporated into multi-DTE molecular architectures, porphyrins are rarely employed as bridges despite their robustness, symmetry and unique opto-electronic properties. Examples of porphyrins bearing two ${ }^{[22]}$ or four ${ }^{[23]}$ azobenzene switches with contrasting photoisomerization capabilities were reported; yet, to date, the only multi-DTE mono-porphyrin scaffolds are a tin(IV) porphyrin with two axially coordinated phenoxide-DTEs ${ }^{[24]}$ and an azaporphyrin with bisthienylethenes incorporated across the beta-positions of all four pyrroles. ${ }^{[16]}$

The combination of DTEs with porphyrins is an appealing way to modulate light-triggered intra- or intermolecular processes, such as electron ${ }^{[25-26]}$ or energy ${ }^{[27]}$ transfer or singlet oxygen generation. ${ }^{[28]}$ Moreover, photochromic compounds displaying reversible fluorescence switching properties are of great interest in the field of superresolution fluorescence microscopy, for the fabrication of rewritable fluorescent photoinks. ${ }^{[12]}$ or as phototriggered fluorescent probes. ${ }^{\text {[29-31] }}$

Porphyrins luminesce intensely in the red part of the visible light spectrum where the open DTE isomer does not absorb. Moreover, porphyrin emission occurs upon excitation with visible light, at wavelengths at which DTE photochromism is not triggered. Thus, readout by fluorimetry can occur at a wavelength far from that required for photoisomerization, in the UV region. In addition, spectral overlap of the closed DTE's absorption in the visible region with the emission band of the porphyrin provides a means of regulating their luminescence, as demonstrated by quenching of the emission upon photoisomerization. ${ }^{[24,26,32-34]}$ Porphyrins also offer a possible large energy difference between the excitation and emission wavelengths, e.g. by excitation of the Soret band ca. $420 \mathrm{~nm}$ and emission at $650 \mathrm{~nm}$; this difference exceeds the normal Stokes shift when excitation occurs in the $Q$ band. This large shift facilitates detection of the emission and avoids scattering from the excitation light, thus opening the door to applications as "rewritable fluorescent photoinks." 


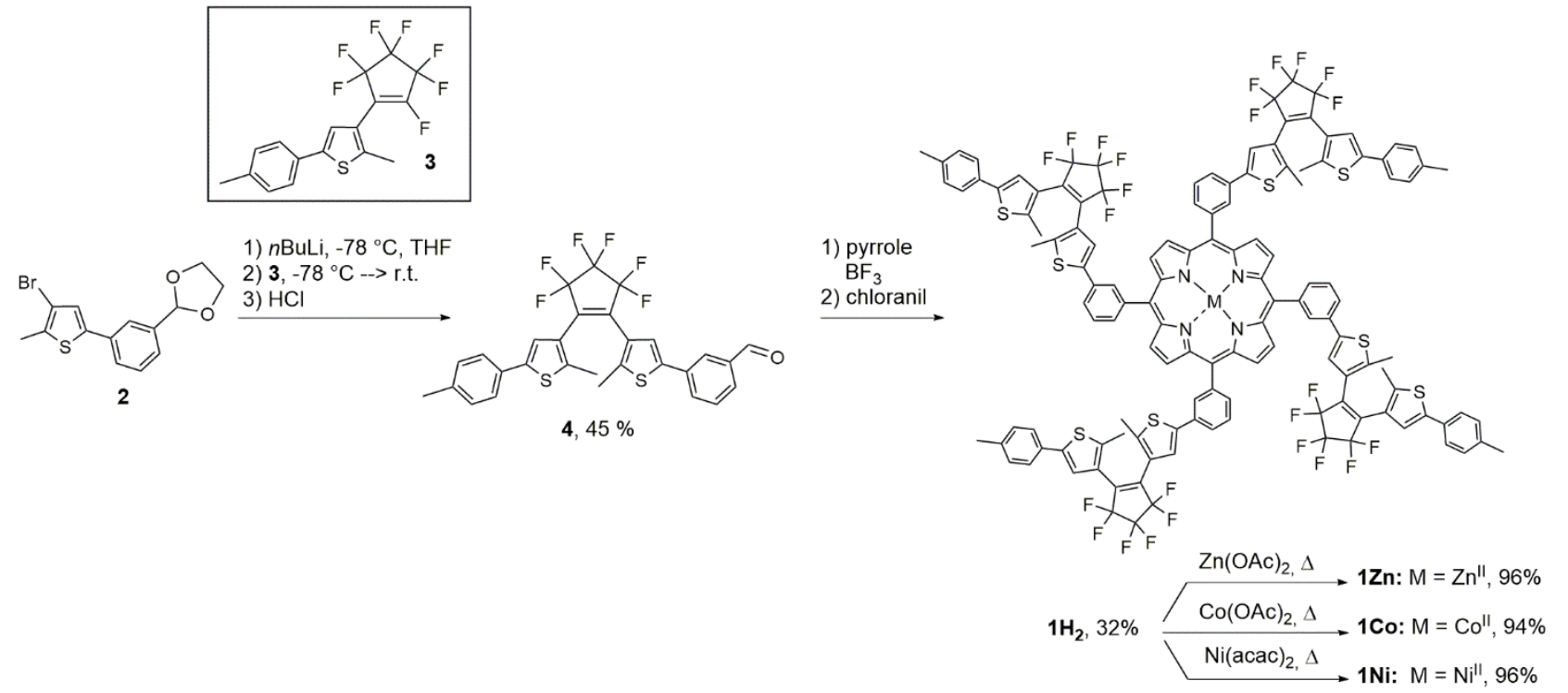

Scheme 1. Synthesis of free base and metallated tetra-DTE porphyrins.

With the aim of designing molecular switches with high contrast, an emissive porphyrin was used as a symmetric framework for four DTE units. Thus, we synthesized four photoswitchable compounds (Scheme 1), namely the free base $\mathbf{1 H}_{\mathbf{2}}$ and the corresponding metal derivatives $(\mathbf{1 Z n}, \mathbf{1} \mathbf{C o}, \mathbf{1} \mathbf{N i})$. The free base and zinc derivatives should ensure efficient luminescence commutation. The four DTE units were incorporated at the meta position of a tetraphenylporphyrin core not only to avoid the formation of atropoisomers, but also to limit electronic communication between the porphyrin ring and the DTEs. Reduced electronic communication between the porphyrin and the DTE chromophores should preserve the photochromic behavior of the DTE units. The photochromic properties of these scaffolds were monitored by ${ }^{1} \mathrm{H}$ NMR, UV-visible absorption and emission spectroscopies. Furthermore, using confocal laser scanning microscopy, photopatterning of fluorescence was also demonstrated for bi-component films of $\mathbf{1} \mathbf{H}_{\mathbf{2}}$ embedded in a polystyrene matrix.

\section{Results and Discussion}

\section{Synthesis}

The synthesis of the tetra-DTE metal-free porphyrin $\mathbf{1 H}_{\mathbf{2}}$ was achieved in $32 \%$ yield by Lewis acid catalyzed condensation ${ }^{[35]}$ of the DTE-based aldehyde $\mathbf{4}$ with pyrrole and subsequent oxidation with $p$-chloranil (Scheme 1). The unsymmetrically substituted DTE 4 was prepared by a reported procedure ${ }^{[5 b]}$ from the 4bromothiophene derivative $2^{[36]}$ bearing a protected benzaldehyde and the perfluorocyclopentene derivative $3,{ }^{[37]}$ followed by deprotection of the aldehyde under acidic conditions. An inert tolyl substituent was chosen for the end of the DTE arms to facilitate characterization by ${ }^{1} \mathrm{H}$ NMR during photoisomerization experiments. Metalloporphyrins $\mathbf{1 Z n}, \mathbf{1 C o}$ and $\mathbf{1 N i}$ were prepared in excellent yields by reaction of $\mathbf{1} \mathbf{H}_{\mathbf{2}}$ with the corresponding metal salt, i.e., $\mathrm{Zn}(\mathrm{OAc})_{2}, \mathrm{Co}(\mathrm{OAc})_{2}$ and $\mathrm{Ni}(\mathrm{acac})_{2}$ respectively.

Except for the paramagnetic $\mathbf{1 C o}$, compounds $\mathbf{1 H}_{2}, \mathbf{1} \mathbf{N i}$ and $1 \mathrm{Zn}$ were characterized by ${ }^{1} \mathrm{H}$ NMR spectroscopy $\left(\mathrm{CD}_{2} \mathrm{Cl}_{2}\right)$. The presence of a single peak for the beta-pyrrolic protons near $9 \mathrm{ppm}$ confirms the four-fold symmetry of the molecules. Typically, the spectrum of $\mathbf{1} \mathbf{H}_{2}$ (Figure 1, bottom) exhibits two singlets at $\delta 7.46$ and $\delta 7.18 \mathrm{ppm}$, assigned to the magnetically non-equivalent thienyl protons of the four DTE units in their open forms, whereas the protons of the methyl groups appear as one broad signal at $\delta$ $1.95 \mathrm{ppm}$. The ${ }^{1} \mathrm{H}$ NMR spectra of metal-based porphyrins $\mathbf{1 Z n}$ and $\mathbf{1 N i}$ display similar NMR features for the DTE protons.

The electronic absorption spectrum of each tetra-DTEporphyrin array shows the typical features of the two chromophores, with a broad band in the UV region attributed to the $\pi-\pi^{*}$ transitions of the open-DTE in addition to the porphyrin's characteristic Soret and $Q$ bands in the visible region (Table 1 and $E S I)$. Four $Q$ bands are observed for $\mathbf{1 H}_{2}$ at $517,551,590$ and $646 \mathrm{~nm}$ (Figure 2, Table 1 and ESI). Fewer (two or one) Q bands are observed for the metallated porphyrins $1 \mathrm{Zn}$ (Figure 2 and ESI), $\mathbf{1} \mathrm{Ni}$ and $\mathbf{1 C o}(\mathrm{ESI})$ due to their four-fold symmetry.

\section{Photochromism}

The photocyclization/cycloreversion reactions of $1 \mathbf{H}_{2}, \mathbf{1 Z n}, \mathbf{1 N i}$ and 1 Co were followed by UV-visible absorption spectroscopy in dichloromethane under UV irradiation (ring closure reaction) and visible irradiation (ring-opening reaction). The photophysical data of the four porphyrins in their initial open state and at the photostationary state (PSS, after irradiation at $312 \mathrm{~nm}$ ) together with their conversions (at PSS) determined by ${ }^{1} \mathrm{H}$ NMR are summarized in Table 1. Upon irradiation of a solution of $\mathbf{1} \mathbf{H}_{\mathbf{2}}$, a broad band appeared in the visible region (500-700 nm), which is characteristic of the formation of closed DTE units (Figure 2, Table 1). Spectral changes were also observed in the UV part of the spectrum with a decrease of the absorption band at $290 \mathrm{~nm}$ and a concomitant increase of the absorption band around 360 $\mathrm{nm}$. In addition, the absorption maximum of the Soret band diminished. Such a hypochromic feature was previously observed for related mono-DTE porphyrins and tentatively attributed to an effective electronic communication through a $p$-phenyl-acetylene linker. ${ }^{[33]}$ However, in the present work, the Soret band displays a broadening which can explain an apparent hypochromism in the absence of ground state electronic interactions. Under similar conditions, the electronic spectra of metallated porphyrins $1 \mathbf{Z n}$, $1 \mathrm{Ni}$ and $1 \mathrm{Co}$ display the characteristic low-energy absorption band at $500-700 \mathrm{~nm}$, indicative of ring-closure processes (see 
ESI). All photocyclization processes are reversible. Upon photoexcitation at $580 \mathrm{~nm}$, the closed forms of all four compounds were converted back to their initial open forms and the electronic absorption spectra, notably the Soret band, were fully recovered in all cases (see ESI). A lack of electronic communication in the ground state between the four DTE units on each molecule is supported by the presence of distinct isosbestic points in the absorption spectra of all four compounds. ${ }^{[14 \mathrm{c}, \mathrm{d}]}$ Finally, no degradation was observed after several irradiation cycles (UV $\leftrightarrow$ visible), demonstrating the reversible photochromic behavior of these compounds.

Upon irradiation of a $\mathrm{CD}_{2} \mathrm{Cl}_{2}$ solution of $\mathbf{1 H}_{2}$ at $300 \mathrm{~nm}$, the ${ }^{1} \mathrm{H}$ NMR spectrum shows the characteristic upfield-shifted signals of the two thienyl protons of the closed DTEs at $\delta 6.85$ and 6.65 ppm, (Figure 1, top) whereas the magnetically non-equivalent methyl protons appear as two singlets shifted downfield, at $\delta 2.36$ and $2.23 \mathrm{ppm}$, compared to the methyl proton of the open DTEs (Figure S12). The signals of the open-DTE units are still present at the PSS, but it is not possible to discriminate between those of the initial fully open species (e.g. when all four DTE units on $\mathbf{1}$ are in the open-state) and the photo-generated open-closed derivatives. Therefore, in addition to the fully-open and -closed tetra-DTE-based porphyrin, the PSS is likely to contain a mixture of various isomers $(\mathrm{o}, \mathrm{O}, \mathrm{O}, \mathrm{C}, ; \mathrm{O}, \mathrm{O}, \mathrm{C}, \mathrm{C} ; \mathrm{O}, \mathrm{c}, \mathrm{O}, \mathrm{C} ; \mathrm{O}, \mathrm{C}, \mathrm{C}, \mathrm{C} \ldots)$, in which one, two, three or four DTE units are photocyclized. Moreover, a new low field singlet at $\delta 8.85 \mathrm{ppm}$ is attributed to the $\beta$-pyrrolic protons of the photocyclized species.

The percentage of ring-closing in the photostationary state was determined by ${ }^{1} \mathrm{H}$ NMR spectroscopy (in $\mathrm{CD}_{2} \mathrm{Cl}_{2}$ ), by calculating the ratio of the integration between the thienyl signals of the closed DTE units and that of the $\beta$-pyrrolic protons, both in the open and PSS states. The photocyclization conversion was estimated to be 62,88 , and $75 \%$ for compounds $1 \mathbf{H}_{2}, \mathbf{1 Z n}$ and $\mathbf{1 N i}$ respectively (Table 1 ). The higher conversion rate found for the metalled species could be explained by a ring-closure via the triplet state of open-DTE units, due to intersystem crossing. ${ }^{[6,38]}$ Notably, the efficiency at which these porphyrin-DTE scaffolds 1 photocyclize contrasts the reported inhibition of photoisomerization in several compounds in which porphyrins and the switching unit are linked by an ortho- or para-substituted phenyl spacer. ${ }^{[22 b, 23,33,39]}$ The meta substitution pattern in our edifices appears to limit efficiently the electronic delocalization in the molecular framework.

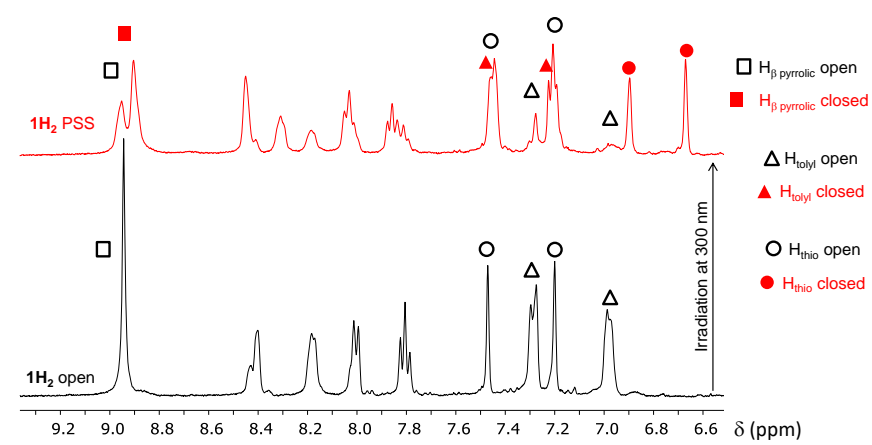

Figure 1. Partial ${ }^{1} \mathrm{H}$ NMR spectra $\left(300 \mathrm{MHz}, \mathrm{CD}_{2} \mathrm{Cl}_{2}\right)$ of $\mathbf{1} \mathbf{H}_{2}$; bottom: fully-open isomer, top: after irradiation with $300 \mathrm{~nm}$ light.
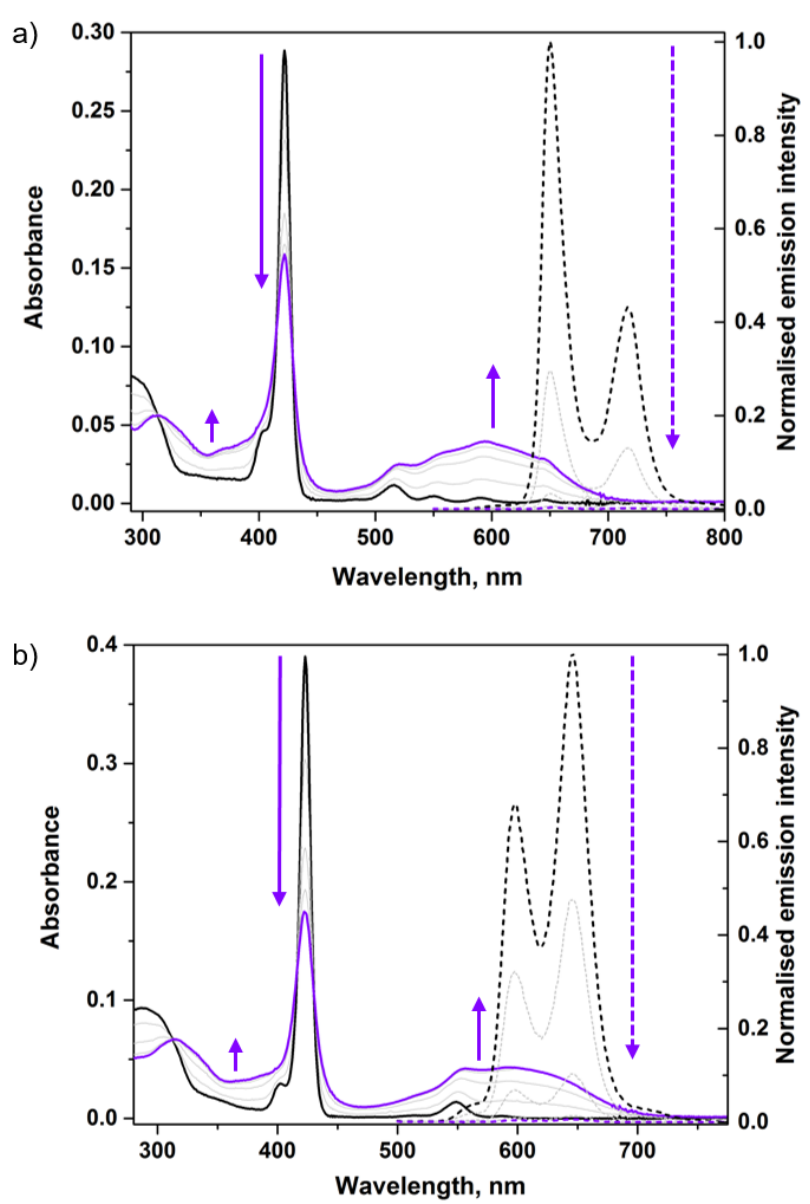

Figure 2. a) UV-visible absorption (solid line) and emission spectra (dashed line, $\left.\lambda_{\text {exc }}=429 \mathrm{~nm}\right)$ of $\mathbf{1 H}_{\mathbf{2}}$ in $\mathrm{CH}_{2} \mathrm{Cl}_{2}\left(5 \times 10^{-7} \mathrm{M}\right)$ upon irradiation at $312 \mathrm{~nm}$. b) UVvisible absorption (solid line) and emission spectra (dashed line, $\lambda_{\mathrm{exc}}=430 \mathrm{~nm}$ ) of $1 \mathrm{Zn}$ in $\mathrm{CH}_{2} \mathrm{Cl}_{2}\left(5 \times 10^{-7} \mathrm{M}\right)$ upon irradiation at $312 \mathrm{~nm}$.

\section{Fluorescence properties of $1 \mathrm{H}_{2}$ and $1 \mathrm{Zn}$ - open-form}

The emission spectra $1 \mathrm{H}_{2}$ and $1 \mathrm{Zn}$ measured at room temperature, in non-deaerated $\mathrm{CH}_{2} \mathrm{Cl}_{2}$, exhibit features analogous to their counterparts without DTE units, namely the free base $\left(\mathrm{H}_{2}\right.$ TPP) and the zinc-tetraphenylporphyrin ${ }^{[40]}$ (ZnTPP). The emission spectrum of $\mathbf{1} \mathbf{H}_{2}$ displays two peaks, $\mathrm{Q}(0-0)$ and $\mathrm{Q}(0-1)$, respectively at 650 and $717 \mathrm{~nm}$ (Figure 2, Table 1 and $\mathrm{ESI})$, whereas the excitation spectrum $\left(\lambda_{\mathrm{em}}=715 \mathrm{~nm}\right)$ shows the same features as displayed by the absorption spectrum (see ESI). $1 \mathrm{H}_{2}$ displays a fluorescence quantum yield $\Phi_{\mathrm{F}}=7.9 \pm 0.3 \%$ in $\mathrm{CH}_{2} \mathrm{Cl}_{2}$ in the open form, which is in good agreement with the homologous, non-photochromic $\mathrm{H}_{2}$ TPP, for which $\Phi_{\mathrm{F}}=10 \%$ in toluene. ${ }^{[40]}$ The lifetime for the radiative decay of $S_{1}$ of $\mathbf{1} \mathbf{H}_{2}$ in the open form displays a monoexponential decay, with $\tau=8.97 \pm 0.03$ ns $\left(\lambda_{\mathrm{em}}=650 \mathrm{~nm}, \lambda_{\mathrm{exc}}=590 \mathrm{~nm}\right)$, in agreement with literature values for $\mathrm{H}_{2}$ TPP ( $\tau=12 \mathrm{~ns}$ in benzene). ${ }^{[41]}$

Interestingly, the metallated compound $1 \mathbf{Z n}$ displays radiative deactivation from both $S_{2}-S_{0}$, with a maximum at 426 $\mathrm{nm}$, and $\mathrm{S}_{1}-\mathrm{S}_{0}$, with two maxima at 597 and $646 \mathrm{~nm}$ for $\mathrm{Q}(0-0)$ and $Q(0-1)$ respectively, in a fashion analogous to ZnTPP ${ }^{[42]}$ (see $\mathrm{ESI}$ ). The same considerations made for the excitation spectrum of $\mathbf{1} \mathbf{H}_{2}$ are also valid for $\mathbf{1 Z n}$ (see ESI). In the open form, $\mathbf{1 Z n}$ displays a fluorescence quantum yield $\Phi_{F}=4.8 \pm 0.2 \%$ (for the $S_{1}$ - $\mathrm{S}_{0}$ transition) in $\mathrm{CH}_{2} \mathrm{Cl}_{2}$ that is slightly higher, but still close to the homologous ZnTPP, showing $\Phi_{F}=3.3 \%$ in toluene. ${ }^{[40]}$ 
Table 1. Photophysical properties of open-DTE and closed-DTE derivatives (PSS) of $\mathbf{1} \mathbf{H}_{\mathbf{2}}, \mathbf{1} \mathbf{N i}, \mathbf{1 Z n}$ and $\mathbf{1 C o}$ together with their photocyclization conversions

\begin{tabular}{|c|c|c|c|c|c|c|c|c|c|c|c|c|c|}
\hline & \multirow[b]{3}{*}{ DTE } & \multicolumn{5}{|c|}{$\lambda_{\max }$ open form $[\mathrm{nm}]\left(\varepsilon \times 10^{-3}\left[\mathrm{M}^{-1} \mathrm{~cm}^{-1}\right]\right)^{[\mathrm{a}]}$} & \multirow{3}{*}{$\begin{array}{c}\lambda_{\max } \\
\text { closed } \\
\text { form at } \\
\text { PSS } \\
{[\mathrm{nm}]^{[\mathrm{b}]}}\end{array}$} & \multicolumn{3}{|c|}{$\lambda_{\mathrm{em}}$ open form $[\mathrm{nm}]^{[\mathrm{a}]}$} & \multicolumn{2}{|c|}{$\boldsymbol{\Phi}_{F}[\%]^{[c]}$} & \multirow{3}{*}{$\begin{array}{c}\% \\
\text { Closeo } \\
\text { form at } \\
\text { PSS }^{[d]}\end{array}$} \\
\hline & & & & & & & & \multirow[b]{2}{*}{$\mathrm{S}_{2}-\mathrm{S}_{0}$} & \multicolumn{2}{|c|}{$S_{1}-S_{0}$} & \multirow{2}{*}{$\begin{array}{l}\text { Open } \\
\text { form }\end{array}$} & \multirow[b]{2}{*}{ PSS } & \\
\hline & & Soret $(0-0)$ & $Q_{y}(1-0)$ & $Q_{y}(0-0)$ & $Q_{x}(1-0)$ & $Q_{x}(0-0)$ & & & $\begin{array}{c}Q \\
(0-0)\end{array}$ & $\begin{array}{c}\mathrm{Q} \\
(0-1) \\
\end{array}$ & & & \\
\hline $1 \mathrm{H}_{2}$ & $290(160)$ & $422(580)$ & $516(24)$ & $550(9.4)$ & $590(7.1)$ & $646(4.4)$ & 307,593 & & 650 & 717 & $7.9 \pm 0.3$ & $0.05 \pm 0.01$ & 62 \\
\hline $1 \mathrm{Ni}$ & $285(170)$ & $417(300)$ & 527 (19) & $553(1.6)$ & & & 310,589 & & & & & & 75 \\
\hline $1 Z n$ & 287 (190) & $423(780)$ & $549(28)$ & $586(4.2)$ & & & 311,592 & 426 & 597 & 646 & $4.8 \pm 0.2$ & $0.04 \pm 0.02$ & 88 \\
\hline $1 \mathrm{Co}$ & $290(120)$ & $414(280)$ & $529(15)$ & & & & 312,591 & & & & & & $-[\mathrm{e}]$ \\
\hline
\end{tabular}

[a] $5 \times 10^{-7} \mathrm{M}$ in $\mathrm{CH}_{2} \mathrm{Cl}_{2}, 298 \mathrm{~K}$; [b] PSS attained under irradiation at $\lambda=312 \mathrm{~nm}$. [c] $\Phi_{\mathrm{F}}$ fluorescence quantum yield for the $\mathrm{S}_{1}-\mathrm{S}_{0}$ transition of $1 \mathrm{H}_{2}$ and $1 \mathrm{Zn}$ in the open form and at the PSS (irr. $312 \mathrm{~nm}$ ) determined by comparison with standard free base tetraphenylporphyrin $\left(\mathrm{H}_{2} T P P\right)$, for which $\Phi_{F}, R=0.10$ in toluene. ${ }^{[40]}$ [d] Determined by ${ }^{1} \mathrm{H}$ NMR. [e] Not determined by ${ }^{1} \mathrm{H}$ NMR due to the paramagnetic nature of the cobalt(II).

For $1 \mathrm{Zn}$ in the open form, the lifetime of $\mathrm{S}_{1}-\mathrm{S}_{0}$ emission showed a monoexponential decay, with $\tau=1.9 \pm 0.1 \mathrm{~ns}\left(\lambda_{\mathrm{em}}=647 \mathrm{~nm}, \lambda_{\mathrm{exc}}\right.$ $=560 \mathrm{~nm})$, in agreement with literature values for $\operatorname{ZnTPP}(\tau=2$ ns in benzene). ${ }^{[41]}$

\section{Photoinduced modulation of $\mathbf{1 H}_{\mathbf{2}}$ and $\mathbf{1 Z n}$ fluorescence}

As a direct consequence of the photochromism of the DTE units covalently linked to the porphyrin core, for both the fluorescent $\mathbf{1} \mathbf{H}_{2}$ and $\mathbf{1 Z n}$ a quenching of their emission was noticed upon DTE closure triggered by UV light. Interestingly, the phenomenon was reversible, with the recovery of the original fluorescence upon visible $(490 \leq \lambda \leq 570 \mathrm{~nm}$ ) light irradiation, thus confirming the DTEs' role in the variation of the emission of $1 \mathbf{H}_{2}$ and $\mathbf{1 Z n}$. The emission spectra (Figure 1 and $\mathrm{ESI}$ ) were recorded upon excitation of the fluorophore in non-deaerated solutions in $\mathrm{CH}_{2} \mathrm{Cl}_{2}$ at one isosbestic point of the absorption spectra (429 and $430 \mathrm{~nm}$ for $1 \mathbf{H}_{2}$ and $\mathbf{1 Z n}$, respectively) to rule out any variation of the emission spectra due to a change in the absorption of the excitation light upon DTE isomerization. Nevertheless, experiments performed at different excitation wavelengths showed the same phenomenon. Quenching of the fluorescence of the emissive free base porphyrin $\mathbf{1 H}_{2}$ and the metallated $\mathbf{1 Z n}$ was seen upon DTE ring closure (Figure 2). In addition, for $\mathbf{1 Z n}$, emission from $S_{2}\left(\lambda_{\text {em }}=426 \mathrm{~nm}\right.$ ) was efficiently quenched upon DTE closure by UV irradiation (see ESI).

To assign the nature of the emissive species, excited state lifetime measurements were also performed upon DTE switching after UV irradiation. Upon partial switching of $\mathbf{1 H}_{\mathbf{2}}$ (short UV irradiation), the measurement showed a biexponential decay, with $\tau_{1}=9 \pm 2 \mathrm{~ns}$, and $\tau_{2}=7.7 \pm 0.8 \mathrm{~ns}$ and relative amplitudes of $82 \%$ and $18 \%$, respectively. Upon further switching (longer UV irradiation), the signal's intensity was too low to perform meaningful measurements. From these results, it seems evident that upon (short) irradiation a second species with shorter emission lifetime appears. This species could be a partially closed-DTE isomer that still emits light, but partial emission quenching is visible following its shorter lifetime. Upon increasing UV irradiation, the emission becomes so weak that no lifetime is measurable, which reflects a low concentration of the emissive species. Unfortunately, lifetime measurements on partially switched $1 \mathrm{Zn}$ were not performed because, due to instrumental limitations, the signal was too weak (nonoptimal excitation wavelength) to record.

At the PSS, attained upon UV light (312 nm) irradiation, $\mathbf{1} \mathbf{H}_{\mathbf{2}}$ and 1Zn displayed luminescence quantum yields of $\Phi_{\mathrm{F}}=0.05 \pm$ $0.01 \%$ and $\Phi_{F}=0.04 \pm 0.02 \%$, respectively. Here it is appropriate to state that the measurements were performed not on a single species, but most likely on a mixture of different, partially closed DTE isomers. Residual emission at the PSS (upon UV irradiation) therefore resulted from the presence of low concentrations of allopen and a partially closed isomer. This hypothesis is consistent with the low contrast in fluorescence intensity upon DTE photoswitching for similar reported compounds containing one or two DTE units. ${ }^{[2,31]}$ Overall, both compounds provided an excellent contrast between the emission spectra of the all-open and PSS states, mainly because of the presence of multiple quenchers around the fluorophore.

Multiple DTE switching cycles were performed and fluorescence intensity was recorded to explore the reversibility and resistance to fatigue of $\mathbf{1} \mathbf{H}_{2}$ and $\mathbf{1 Z n}$ (Figure 3). The intensity at the maximum of the fluorescence band was recorded at each irradiation step, upon excitation at the isosbestic point, as described earlier. $\mathbf{1 H}_{\mathbf{2}}$ showed almost complete reversibility, having recovered $85 \%$ of the initial emission intensity after 10 irradiation cycles in $\mathrm{CH}_{2} \mathrm{Cl}_{2}$, whereas $1 \mathbf{Z n}$, after the same number of cycles, displayed only $40 \%$ of the initial emission intensity. The latter is a clear indication of the lower photostability upon multiple irradiation cycles displayed by $\mathbf{1 Z n}$ compared to its free base analogue. Nevertheless, the mechanism of photodegratation is still unknown and will be the subject of future investigations.

\section{Photo-rewritable fluorescence patterning on $1 \mathrm{H}_{2}$-doped polystyrene films on glass}

Fluorescence switching of the free base porphyrin $\mathbf{1} \mathbf{H}_{2}$ was also performed on thin films of a blend of $\mathbf{1 H}_{2}(8 \%$ in weight) and polystyrene (PS, average molecular weight $=500 \mathrm{kDa}$ ) spincoated on glass substrates. The film on glass displayed absorption and emission spectra analogous to those shown by $\mathbf{1} \mathbf{H}_{2}$ in its fully open form in $\mathrm{CH}_{2} \mathrm{Cl}_{2}$ solution (Figure 4). Moreover, photochromism of DTE and hence the photoswitchable fluorescence properties were retained, as observed in the emission spectra. 

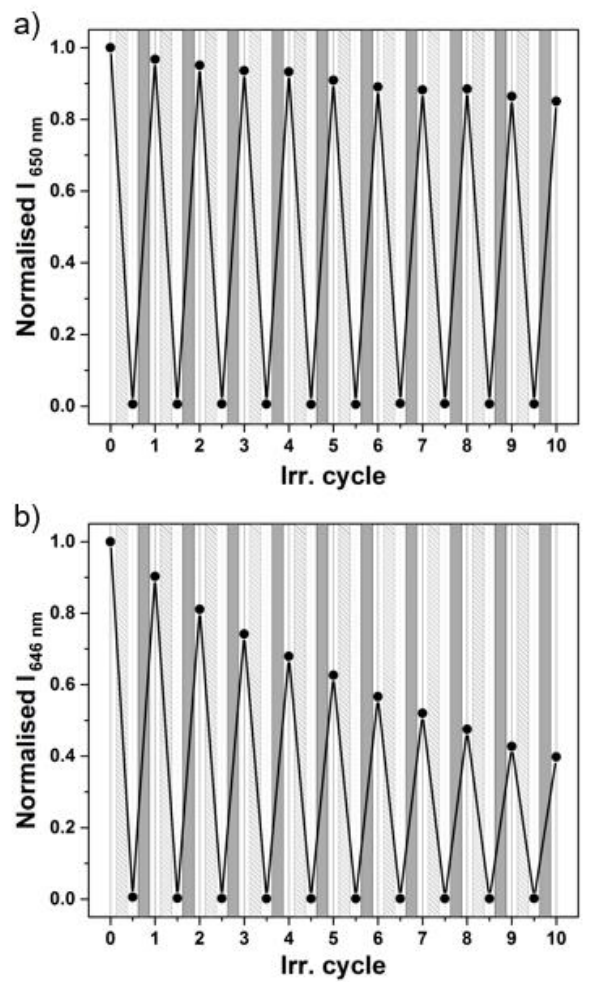

Figure 3. Variation of the emission intensity of a) $\mathbf{1} \mathbf{H}_{\mathbf{2}}$ and b) $\mathbf{1 Z n}$ upon DTE isomerization by UV irradiation (light grey area, $312 \mathrm{~nm}$; $\mathrm{t}=40 \mathrm{~s}, \mathrm{P}_{\mathrm{d}}=3.0 \mathrm{~mW}$ $\mathrm{cm}^{-2}$ ) and subsequent ring opening by visible irradiation (dark grey area, green bandpass filter $\lambda_{\max }=530 \mathrm{~nm}, \mathrm{FWHM}=80 \mathrm{~nm} ; \mathrm{t}=90 \mathrm{~s}, \mathrm{P}_{\mathrm{d} @ 530 \mathrm{~nm}}=57.0 \mathrm{~mW}$ $\left.\mathrm{cm}^{-2}\right)$ in $\mathrm{CH}_{2} \mathrm{Cl}_{2}\left(5.0 \times 10^{-7} \mathrm{M}\right)$. Emission spectra were recorded in non-degassed $\mathrm{CH}_{2} \mathrm{Cl}_{2}$ solution $\left(\mathrm{c}=5.0 \times 10^{-7} \mathrm{M}\right.$ ) upon excitation at $429 \mathrm{~nm}$ for $\mathbf{1 H}_{2}$ and $430 \mathrm{~nm}$ for $1 \mathrm{Zn}$; the emission intensity was taken at the maximum of the fluorescence band $\left(650 \mathrm{~nm}\right.$ for $\mathbf{1} \mathbf{H}_{\mathbf{2}}$ and $646 \mathrm{~nm}$ for $\left.\mathbf{1 Z n}\right)$

To understand the reversibility of the processes, multiple irradiation cycles were performed and showed the recovery of the initial emission intensity (Figure 4b). Nevertheless, due to limitations of the experimental setup, the data could only be used to show qualitatively ${ }^{[43]}$ that the photoswitching properties of $\mathbf{1 H}_{\mathbf{2}}$ were retained when the latter was dispersed into an amorphous polymer matrix and deposited as a thin film on a solid substrate.

Following the success in measuring the reversible fluorescence switching in films of $\mathbf{1 H}_{\mathbf{2}}$ with $\mathrm{PS}$, we investigated the use of such a blend as a photoink for rewritable fluorescence patterning of thin films made on solid substrates. After deposition of the aforementioned blend as described earlier, positive and negative fluorescent patterns were recorded by structured illumination using a confocal laser scanning microscope (Figure 5). The reversible photoactivated luminescence quenching was exploited to record multiple patterns, by scanning with a UV laser (355 nm, $20 \mathrm{~s}$ scan) to trigger DTE ring-closure, therefore turning off the emission (dark areas, Figure 5), or with a visible laser (405 $\mathrm{nm}, 30 \mathrm{~s}$ scan) to trigger DTE ring-opening and to restore the original emission of the free-base porphyrin (bright areas, Figure $5)$. Based on the limitations of our instrumental set-up, the light source (visible laser, $\lambda=405 \mathrm{~nm}$ ) employed for writing was also used for the luminescence read-out of the recorded patterns. Nevertheless, for imaging purposes, the use of lower laser power and scanning time sufficed to preserve the written information.
The successful demonstration of the utilization of the phototunable fluorescence properties of $\mathbf{1 H}_{\mathbf{2}}$ highlights its potential application as a photo-rewritable fluorescent ink for rewritable optical memory media or imaging purposes.

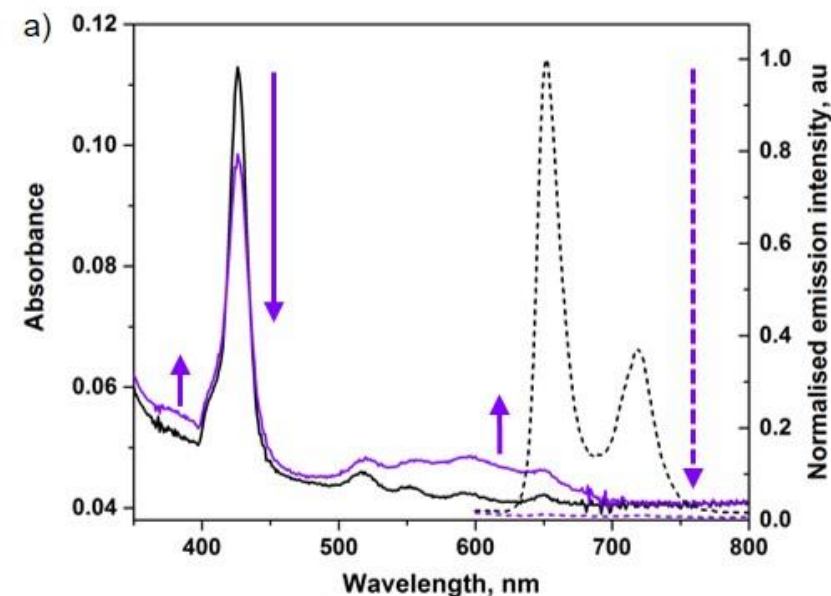

b)

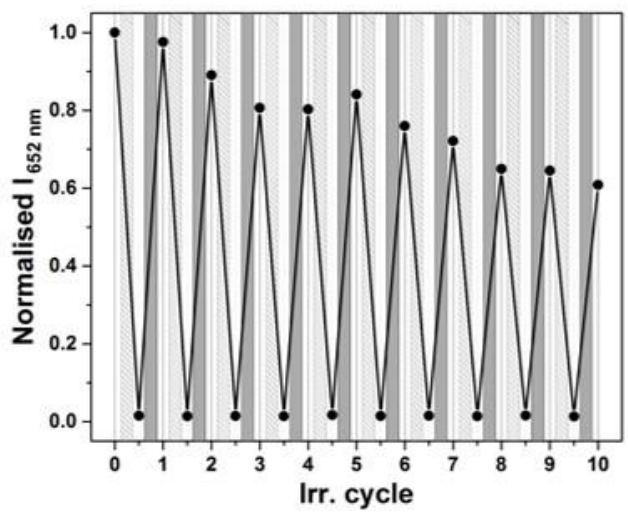

Figure 4. a) Absorption and emission spectra of $\mathbf{1} \mathbf{H}_{\mathbf{2}}$ in doped polystyrene film (500 kDa polystyrene, $\left.8 \% \mathrm{w} / \mathrm{w} \quad \mathbf{1 H}_{2}\right)$ spin-casted on glass upon DTE

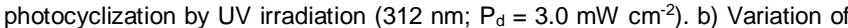
the emission intensity of $\mathbf{1 H}_{\mathbf{2}}$ upon alternated UV irradiation (light grey area, 312 $\mathrm{nm}$ ) and visible irradiation (dark grey area, green bandpass filter $\lambda_{\max }=530 \mathrm{~nm}$ $\mathrm{FWHM}=80 \mathrm{~nm})$ in a doped polystyrene film $\left(500 \mathrm{kDa}\right.$ polystyrene, $\left.8 \% \mathrm{~W} / \mathrm{w} \mathbf{1} \mathbf{H}_{2}\right)$ spin-casted on glass.
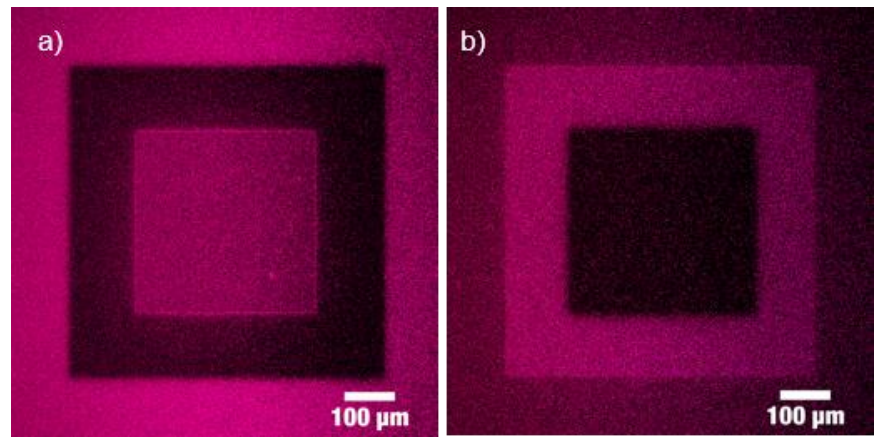

Figure 5. Confocal laser scanning microscope images taken on $\mathbf{1 H}_{\mathbf{2}}$-doped polystyrene film ( $500 \mathrm{kDa}$ polystyrene, $8 \% \mathrm{w} / \mathrm{w} \mathbf{1} \mathbf{H}_{2}$ ) spin-casted on glass. The film was selectively patterned upon subsequent UV or visible laser irradiation by scanning on three square-shaped areas and progressively decreasing the scan size. a) Vis light ( $405 \mathrm{~nm}$ laser, $3 \%$ power, $30 \mathrm{~s}$ ), UV light (355 nm laser, $20 \mathrm{~s}$ ) and Vis light. b) UV light, visible light and UV light. Imaging was performed upon excitation of $\mathbf{1 H}_{2}$ at $\lambda_{\text {exc }}=405 \mathrm{~nm}(0.5 \%$ power, $1.7 \mathrm{~s}$ per frame), collecting emission $414 \leq \lambda_{\mathrm{em}} \leq 721 \mathrm{~nm}$ light 


\section{Conclusions}

The efficient and reversible photoisomerization observed in a family of novel tetra-dithienylethene-substituted porphyrins demonstrates that a high density of functional switching units can be arranged around a porphyrin framework by covalent linkage via a meta-phenyl spacer. The tetra-DTE-porphyrin arrays $\mathbf{1} \mathbf{H}_{2}$ and $\mathbf{1 Z n}$ displayed reversible luminescence switching properties, due to the quenching of the singlet emissive state of the luminophore by intramolecular energy transfer to the closed form of DTE. Upon DTE photoswitching, a nearly complete quenching of the porphyrin's fluorescence was attained, providing a highly contrasted readout of the switching event. In addition to their photoregulated fluorescence, the possibility to trigger the switch and detect the output at very distinct wavelengths renders these systems of interest for applications in optical devices. Moreover, the applicability of $\mathbf{1} \mathbf{H}_{\mathbf{2}}$ as a photo-rewritable fluorescent ink was demonstrated, opening perspectives towards its application in alloptical memory storage and fluorescence microscopy imaging.

\section{Experimental Section}

UV-visible absorption spectroscopy. UV-visible absorption spectroscopy experiments on $\mathbf{1 C o}$ in solution required a degassing procedure on a high-vacuum line in a degassing cell, which consists of a 10-mL Pyrex bulb and a 1-cm path length quartz cuvette, sealed from the atmosphere by a Teflon stopper. Three successive freeze-pump-thaw cycles were performed to degas the solution. For photoisomerization experiments followed by UV-visible absorption spectroscopy of compounds $\mathbf{1 H}_{2}, \mathbf{1 Z n}$ and $\mathbf{1} \mathbf{N i}$, the solutions were not degassed and a 1 $\mathrm{cm}$ quartz cell was used. Photoisomerization in solution was performed with an LS series Light Source of ABET technologies, Inc (150 W xenon lamp), with single wavelength light filters "320FS 10-25" for ring-closure and "580FS 10-25" for cycloreversion. Alternatively, photoisomerisation studies were performed with a Herolab UV 6ML $312 \mathrm{~nm}$ lamp, at an incident power density $P_{d}=3.0 \mathrm{~mW} \mathrm{~cm}^{-2}$ for DTE electrocyclization reaction. Visible light irradiation was carried out using an Edmund Optics illuminator equipped with a $150 \mathrm{~W}$ halogen lamp and a green filter $\left(\lambda_{\max }=\right.$ $530 \mathrm{~nm}, \mathrm{FWHM}=80 \mathrm{~nm}$ ) at an incident power density $P_{\mathrm{d}, 530 \mathrm{~nm}}=57 \mathrm{~mW}$ $\mathrm{cm}^{-2}$, for DTE cycloreversion. During light irradiation, the solutions were always vigorously stirred. Irradiation for ${ }^{1} \mathrm{H}$ NMR experiments was carried out using a Rayonet ${ }^{\circledR}$ with $300 \mathrm{~nm}$ light emitting lamps.

Fluorescence. All the photophysical studies were performed in spectroscopy grade dichloromethane (Sigma Aldrich), using $1 \mathrm{~cm}$ or $3 \mathrm{~mm}$ optical path length Suprasil quartz cuvettes (Hellma). Except for lifetime measurements, the studies were performed at low concentration ( $c$ = $5.0^{*} 10^{-7} \mathrm{M}$ ), to keep the absorbance at the excitation wavelength lower than 0.1 in order to avoid reabsorption of the emitted light. Emission spectra were recorded with an Agilent Cary Eclipse and a Horiba Jobin Yvon Fluorolog FL3-22 fluorometers. Lifetime measurements were performed by single photon counting with a Horiba Jobin Yvon Fluorolog FL3-22 fluorometer equipped with a FluoroHub A+ TCSPC controller and a PPD picosecond single-photon counting detector. Excitation was performed using NanoLED LED light sources (pulse width $\leq 1.3 \mathrm{~ns}$ ), using $\lambda_{\mathrm{exc}}=590 \mathrm{~nm}$ for $\mathbf{1} \mathbf{H}_{2}$ and $\lambda_{\mathrm{exc}}=560 \mathrm{~nm}$ for $\mathbf{1 Z n}$. Following the short lifetime of $1 \mathrm{Zn}$, the excitation pulse profile was deconvoluted by measuring the instrument response function using a scattering dispersion of colloida silica (Ludox - Sigma Aldrich) in water. Quantum yield measurements were carried out by comparison with a standard compound with known quantum yield. For the purpose, free base tetraphenylporphyrin $\left(\mathrm{H}_{2} \mathrm{TPP}\right.$, Sigma Aldrich) in toluene was used, which has $\Phi_{F, R}=0.10 .{ }^{[39]}$ The measurements were performed upon excitation of $\mathbf{1} \mathbf{H}_{\mathbf{2}}$ and $\mathbf{1 Z n}$ at the isosbestic points (429 and $430 \mathrm{~nm}$ respectively) of their absorption spectra upon DTE isomerization, in order to rule out any change in the absorption of the excitation light. Concentration was kept low, in order to have $A_{\lambda \operatorname{exc}} \leq 0.05$.

$\mathbf{1} \mathbf{H}_{2}$ - polystyrene films. $\mathbf{1 H}_{\mathbf{2}}$ was deposited on solid substrates upon blending with high-molecular weight polystyrene (PS, average: 500 kDa Sigma Aldrich, low polydispersity, standard for GPC) in $8 \%$ weight ratio. The solutions were prepared at a PS concentration of $3 \mathrm{mg} \mathrm{mL}^{-1}$ in $\mathrm{CHCl}_{3}$ and deposited on glass by spin-coating. The glass slides (standard microscope slides) were washed following standard cleaning procedure by rinsing with acetone, isopropanol, ethanol and blown with nitrogen, no further surface treatment was performed. The films were characterized by optical microscope and surface profiler, they showed uniform surface coverage and an average thickness of $\sim 20 \mathrm{~nm}$. The photophysical properties of the as-deposited films were measured with a Jasco V-650 spectrophotometer equipped with solid sample holder, and with an Agilen Cary Eclipse fluorometer equipped with a movable solid sample holder, holding the sample in right-angle excitation geometry.

Confocal laser imaging. Fluorescence confocal images were recorded by using a Zeiss LSM 710 confocal microscope system with a $10 \times$ magnification objective. Imaging was performed upon exciting the samples with a continuous wave laser at $\lambda_{\mathrm{exc}}=405 \mathrm{~nm}, 1.7 \mathrm{~s}$ per frame, $0.3 \%$ power. The emission of the assemblies was collected in the range from 414 to $721 \mathrm{~nm}$ by using the lambda-mode option. The raw data recorded by means of the lambda-mode were processed by using linear un-mixing tool option available in the ZEN 2011 software package (Zeiss $\mathrm{GmbH}$, Germany). In order to turn off $\mathbf{1} \mathbf{H}_{\mathbf{2}}$ fluorescence a UV continuous wave laser was used $(\lambda=355 \mathrm{~nm})$, by scanning on the same frame for 20 seconds, while to turn on $\mathbf{1 H}_{2}$ fluorescence the same $\lambda=405 \mathrm{~nm}$ laser for imaging was used, but at higher power, scanning on the frame for 30 seconds.

Synthesis of 4. $n$ Butyl lithium (1.6 M in hexane, $1.2 \mathrm{~mL}, 1.9 \mathrm{mmol}$ ) was slowly added to a solution of bromothiophene $2(566 \mathrm{mg}, 1.74 \mathrm{mmol})$ in dry THF $(20 \mathrm{~mL})$ at $-78{ }^{\circ} \mathrm{C}$ under argon. After $30 \mathrm{~min}$, a solution of 2 methyl-3-(perfluorocyclopent-1-en-1-yl)-5-(p-tolyl)thio-phene $3(662 \mathrm{mg}$, $1.74 \mathrm{mmol}$ ) in dry THF was added and the resulting mixture was allowed to warm to r.t. and stirred for $15 \mathrm{~h} . \mathrm{HCl}(0.5 \mathrm{M}, 10 \mathrm{~mL})$ was then added and the mixture was stirred for $30 \mathrm{~min}$. The solvents were removed in vacuum. The residue was extracted with $\mathrm{CH}_{2} \mathrm{Cl}_{2}$ and washed with saturated $\mathrm{NaHCO}_{3(\mathrm{aq})}$. The combined organic phases were then dried, filtered and evaporated to give a thick brown oil as the crude product. Purification by chromatography over silica gel (cyclohexane/ $\mathrm{CH}_{2} \mathrm{Cl}_{2}(4 / 1)$ ) afforded 4 as a yellowish paste (440 mg, $782 \mu \mathrm{mol}, 45 \%) .{ }^{1} \mathrm{H} \mathrm{NMR}\left(300 \mathrm{MHz}, \mathrm{CDCl}_{3}\right): \delta$ ppm = $10.05(\mathrm{~s}, 1 \mathrm{H}), 8.03(\mathrm{t}, J=1.6 \mathrm{~Hz}, 1 \mathrm{H}), 7.80(\mathrm{~m}, 2 \mathrm{H}), 7.56(\mathrm{t}, J=7.7$ $\mathrm{Hz}, 1 \mathrm{H}$ ), 7.43 (dd, $J=6.4 ; 1.8 \mathrm{~Hz}, 2 \mathrm{H}), 7.37$ (s, 1H), $7.22(\mathrm{~s}, 1 \mathrm{H}), 7.19$ (dd, $J=6.4 ; 1.8 \mathrm{~Hz}, 2 \mathrm{H}), 2.37(\mathrm{~s}, 3 \mathrm{H}), 1.99(\mathrm{~s}, 3 \mathrm{H}), 1.97(\mathrm{~s}, 3 \mathrm{H}) .{ }^{13} \mathrm{C}$ NMR $(75$ $\left.\mathrm{MHz}, \mathrm{CDCl}_{3}\right): \delta \mathrm{ppm}=14.69,14.76,21.34,121.92,123.65,125.72,125.79$, 126.33, 126.39, 129.29, 129.83, 129.92, 130.65, 131.39, 134.53, 137.18, $138.13,140.66,140.85,142.45,142.70,192.01 .{ }^{19} \mathrm{~F}\left(282 \mathrm{MHz}, \mathrm{CDCl}_{3}\right): \delta$ ppm $=-110.9,-111.1,-132.9$. HRMS for $\mathrm{C}_{132} \mathrm{H}_{86} \mathrm{~F}_{24} \mathrm{~N}_{4} \mathrm{~S}_{8}{ }^{+}$calc.: $\mathrm{m} / \mathrm{z}=$ 2439.4308; found: $\mathrm{m} / \mathrm{z}=2439.4356$. HRMS for $\left[\mathrm{C}_{29} \mathrm{H}_{20} \mathrm{~F}_{6} \mathrm{O}_{1} \mathrm{~S}_{2}+\mathrm{Na}\right]^{+}$calc.: $\mathrm{m} / \mathrm{z}=585.0752 ;$ found: $\mathrm{m} / \mathrm{z}=585.0740$.

Synthesis of $\mathbf{1} \mathbf{H}_{2}$. To a degassed solution of $\mathbf{1 0}(341 \mathrm{mg}, 584 \mu \mathrm{mol})$ and pyrrole (40 uL, $584 \mu \mathrm{mol})$ in $\mathrm{CH}_{2} \mathrm{Cl}_{2}(58 \mathrm{~mL})$ and ethanol $(0.44 \mathrm{~mL})$ was added $\mathrm{BF}_{3} . \mathrm{OEt}_{2}(1 \mathrm{M}, 0.19 \mathrm{~mL})$. After $1 \mathrm{~h}, p$-chloranil $(107 \mathrm{mg})$ was added to the solution. After $1 \mathrm{~h}$, solvents were removed under vacuum. Chromatography over silica (cyclohexane/ $\mathrm{CH}_{2} \mathrm{Cl}_{2}$ (3/2)) afforded $\mathbf{1} \mathbf{H}_{\mathbf{2}}$ as purple powder (118 mg, $48 \mu \mathrm{mol}, 32 \%)$. ${ }^{1} \mathrm{H}$ NMR $\left(300 \mathrm{MHz}, \mathrm{CDCl}_{3}\right): \delta \mathrm{ppm}$ $=8.99(\mathrm{~s}, 8 \mathrm{H}), 8.45(\mathrm{~s}, 4 \mathrm{H}), 8.22(\mathrm{~d}, J=7.4 \mathrm{~Hz}, 4 \mathrm{H}), 8.03(\mathrm{dt}, J=7.8 \mathrm{~Hz}$; $1.3 \mathrm{~Hz}, 4 \mathrm{H}), 7.82(\mathrm{t}, J=7.3 \mathrm{~Hz}, 4 \mathrm{H}), 7.53(\mathrm{~s}, 4 \mathrm{H}), 7.36(\mathrm{~d}, J=7.9 \mathrm{~Hz}, 8 \mathrm{H})$ $7.25(\mathrm{~s}, 4 \mathrm{H}), 7.06(\mathrm{~d}, J=7.9 \mathrm{~Hz}, 8 \mathrm{H}), 2.28(\mathrm{~s}, 12 \mathrm{H}), 2.06(\mathrm{~s}, 12 \mathrm{H}), 2.03(\mathrm{~s}$ $12 \mathrm{H}),-2.65(\mathrm{~s}, 2 \mathrm{H}) .{ }^{13} \mathrm{C}$ NMR $\left(125 \mathrm{MHz}, \mathrm{CDCl}_{3}\right): \delta \mathrm{ppm}=14.68,21.12$ 26.95, 29.76, 34.84, 34.97, 96.15, 119.61, 121.83, 123.14, 125.01, 125.47 125.72, 126.22, 127.49, 129.58, 130.49, 131.47, 131.56, 131.87, 134.03, $137.84,140.78,141.86,142.43,142.90 .{ }^{19} \mathrm{~F}\left(282 \mathrm{MHz}, \mathrm{CDCl}_{3}\right): \delta \mathrm{ppm}=$ -110.9, -111.1, -132.9. UV-Vis $\left(\mathrm{CH}_{2} \mathrm{Cl}_{2}, 298 \mathrm{~K}\right): \lambda(\mathrm{nm})\left[\varepsilon\left(\mathrm{M}^{-1} \cdot \mathrm{cm}^{-1}\right)\right] 291$ 
[130,000], 422 [530,000], 517 [21,000], 551 [8,200], 590 [6,300], 646 $[3,900]$. HRMS for $\mathrm{C}_{132} \mathrm{H}_{86} \mathrm{~F}_{24} \mathrm{~N}_{4} \mathrm{~S}_{8}{ }^{+}$calc.: $\mathrm{m} / \mathrm{z}=2439.4308$; found: $\mathrm{m} / \mathrm{z}=$ 2439.4356 .

Synthesis of $1 \mathrm{Zn}$. A solution of $1 \mathrm{H}_{2}(50 \mathrm{mg}, 21 \mu \mathrm{mol})$ and $\mathrm{Zn}(\mathrm{OAc})_{2} \cdot 2 \mathrm{H}_{2} \mathrm{O}$ $(23 \mathrm{mg}, 105 \mu \mathrm{mol})$ in $\mathrm{MeOH}(0.22 \mathrm{~mL})$ and $\mathrm{CHCl}_{3}(2.2 \mathrm{~mL})$ was stirred for $45 \mathrm{~min}$ at r.t. Solvents were removed under vacuum. Chromatography over silica $\left(\mathrm{CH}_{2} \mathrm{Cl}_{2}\right)$ afforded $1 \mathrm{Zn}$ as a dark purple powder $(50 \mathrm{mg}, 20 \mu \mathrm{mol}$, 95\%). ${ }^{1} \mathrm{H} \mathrm{NMR}\left(300 \mathrm{MHz}, \mathrm{CDCl}_{3}\right): \delta \mathrm{ppm}=9.03(\mathrm{~s}, 8 \mathrm{H}), 8.40(\mathrm{~s}, 4 \mathrm{H}), 8.16$ (d, $J=7.6 \mathrm{~Hz}, 4 \mathrm{H}), 7.98(\mathrm{~d}, J=7.6 \mathrm{~Hz}, 4 \mathrm{H}), 7.78(\mathrm{t}, J=7.6 \mathrm{~Hz}, 4 \mathrm{H}), 7.45$ (s, 4H), $7.31(\mathrm{~d}, J=7.9 \mathrm{~Hz}, 8 \mathrm{H}), 7.18(\mathrm{~s}, 4 \mathrm{H}), 7.03(\mathrm{~m}, 8 \mathrm{H}), 2.23(\mathrm{~s}, 12 \mathrm{H})$, $2.00(\mathrm{~s}, 12 \mathrm{H}), 1.98(\mathrm{~s}, 12 \mathrm{H})$. UV-Vis $\left(\mathrm{CH}_{2} \mathrm{Cl}_{2}, 298 \mathrm{~K}\right): \varepsilon(\mathrm{nm})[\varepsilon$ $\left.\left(\mathrm{M}^{-1} \cdot \mathrm{cm}^{-1}\right)\right] 290[130,000], 424[580,000], 549[23,000], 586$ [4,100]. HRMS for $\left[\mathrm{C}_{132} \mathrm{H}_{84} \mathrm{~F}_{24} \mathrm{~N}_{4} \mathrm{~S}_{8} \mathrm{Zn}+\mathrm{Na}\right]^{+}$calc.: $\mathrm{m} / \mathrm{z}=2523.3262$; found: $\mathrm{m} / \mathrm{z}=$ 2523.3192.

Synthesis of $\mathbf{1} \mathrm{Ni}$. A solution of $\mathbf{1 H}_{\mathbf{2}}(50 \mathrm{mg}, 21 \mu \mathrm{mol})$ and $\mathrm{Ni}(\mathrm{acac})_{2}(7 \mathrm{mg}$, $26 \mu \mathrm{mol})$ in $\mathrm{PhCl}(1 \mathrm{~mL})$ was refluxed for $45 \mathrm{~min}$. After cooling to r.t., chromatography over silica $\left(\mathrm{CH}_{2} \mathrm{Cl}_{2}\right)$ afforded $\mathbf{1} \mathrm{Ni}$ as a red powder $(50 \mathrm{mg}$, $20 \mu \mathrm{mol}, 96 \%) .{ }^{1} \mathrm{H}$ NMR $\left(300 \mathrm{MHz}, \mathrm{CDCl}_{3}\right): \delta \mathrm{ppm}=8.85(\mathrm{~s}, 8 \mathrm{H}), 8.20(\mathrm{~s}$ $4 \mathrm{H}), 8.00(\mathrm{~d}, J=7.7 \mathrm{~Hz}, 4 \mathrm{H}), 7.92(\mathrm{~d}, J=7.7 \mathrm{~Hz}, 4 \mathrm{H}), 7.73(\mathrm{t}, J=7.7 \mathrm{~Hz}$, $4 \mathrm{H}), 7.44(\mathrm{~s}, 4 \mathrm{H}), 7.37(\mathrm{~d}, J=8.1 \mathrm{~Hz}, 8 \mathrm{H}), 7.21(\mathrm{~s}, 4 \mathrm{H}), 7.09(\mathrm{~d}, J=8.1$ $\mathrm{Hz}, 8 \mathrm{H}), 2.29$ (s, 12H), 2.00 (s, 12H), 1.97 (s, 12H). UV-Vis $\left(\mathrm{CH}_{2} \mathrm{Cl}_{2}, 298\right.$ $\mathrm{K}): \lambda(\mathrm{nm})\left[\varepsilon\left(\mathrm{M}^{-1} \cdot \mathrm{cm}^{-1}\right)\right] 292[110,000], 418[240,000], 528$ [17,000], 553 $[5,100]$. HRMS for $\mathrm{C}_{132} \mathrm{H}_{84} \mathrm{~F}_{24} \mathrm{~N}_{4} \mathrm{NiS}_{8}{ }^{+}$calc.: $\mathrm{m} / \mathrm{z}=2494.3426$; found: $\mathrm{m} / \mathrm{z}=$ 2494.3609.

Synthesis of $1 \mathrm{Co}$. A solution of $1 \mathrm{H}_{2}(50 \mathrm{mg}, 21 \mu \mathrm{mol})$ and $\mathrm{Co}(\mathrm{OAc})_{2} \cdot 4 \mathrm{H}_{2} \mathrm{O}$ $(42 \mathrm{mg}, 168 \mu \mathrm{mol})$ in $\mathrm{MeOH}(1 \mathrm{~mL})$ and $\mathrm{CHCl}_{3}(2 \mathrm{~mL})$ was refluxed for 1 h. After cooling to r.t., solvents were removed under vacuum. The residue was dissolved in $\mathrm{CH}_{2} \mathrm{Cl}_{2}(5 \mathrm{~mL})$ and washed with $\mathrm{H}_{2} \mathrm{O}(2 \times 5 \mathrm{~mL})$. The organic layer was reduced under vacuum. Chromatography over silica (cyclohexane/ $\mathrm{CH}_{2} \mathrm{Cl}_{2}(5 / 1)$ ) afforded $1 \mathrm{Co}$ as a red powder ( $49 \mathrm{mg}, 19 \mu \mathrm{mol}$, 93\%). HRMS for $\mathrm{C}_{132} \mathrm{H}_{84} \mathrm{CoF}_{24} \mathrm{~N}_{4} \mathrm{~S}_{8}{ }^{+}$calc.: $\mathrm{m} / \mathrm{z}=2495.3405$; found: $\mathrm{m} / \mathrm{z}=$ 2495.3445. UV-Vis $\left(\mathrm{CH}_{2} \mathrm{Cl}_{2}, 298 \mathrm{~K}\right): \lambda(\mathrm{nm})\left[\varepsilon\left(\mathrm{M}^{-1} . \mathrm{cm}^{-1}\right)\right] 290[120,000]$, $414[280,000], 529[15,000]$

\section{Acknowledgements}

This work was supported by the Agence Nationale de la Recherche through the Labex projects CSC (ANR-10-LABX-0026 CSC) within the Investissement d'Avenir program (ANR-10-120 IDEX-0002-02), by the International Center for Frontier Research in Chemistry (JWe-CSC-0001), by the Université de Strasbourg, the Centre National de la Recherche Scientifique and the Université de Rennes as well as by the European Commission through the Marie Sklodowska-Curie project ITN project iSwitch (GA-642196). We gratefully acknowledge Dr. Sara Bonacchi and Marco A. Squillaci for enlightening discussions, and Dr. Alessandro Aliprandi for the confocal laser scanning microscope images.

Keywords: photochromism • dithienylethene • porphyrinoids • fluorescence $\cdot$ photopatterning

[1] (a) M. M. Russew, S. Hecht, Adv. Mater. 2010, 22, 3348-3360; (b) X Zhang, L. Hou, P. Samorì, Nat. Commun., 2016, 7, 11118.

[2] (a) M. Irie, Chem. Rev. 2000, 100, 1685-1716; (b) H. Tian, S.Yang, Chem. Soc. Rev. 2004, 33, 85-97; (c) M. Irie, T. Fukaminato, K. Matsuda, S. Kobatake, Chem. Rev. 2014, 114, 12174-12277.

[3] (a) E. Orgiu, N. Crivillers, M. Herder, L. Grubert, M. Pätzel, J. Frisch, E. Pavlica, G. Bratina, N. Koch, S. Hecht, P. Samorì, Nat. Chem. 2012, 4 675-679; (b) T. Mosciatti, M. G. del Rosso, M. Herder, J. Frisch, N. Koch, S. Hecht, E. Orgiu, P. Samorì, Adv. Mater., 2016, 28, 6606-6611.
[4] E. Orgiu, P. Samorì, Adv. Mater. 2014, 26, 1827-1845.

[5] For selected examples of photochromic modulation of fluorescence, see G. M. Tsivgoulis, J.-M. Lehn, Angew. Chem. Int. Ed. 1995, 34, 1119 1122; (b) A. Fernandez-Acebes, J. M. Lehn, Chem. Eur. J. 1999, 5, 3285 3292; (c) T. Kawai, T. Sasaki, M. Irie, Chem. Commun. 2001, 711-712; (d) M. Irie, T. Fukaminato, T. Sasaki, N. Tamai, T. Kawai, Nature, 2002 420, 759-760; (e) T. Fukaminato, T. Sasaki, T. Kawai, N. Tamai, M. Irie, J. Am. Chem. Soc. 2004, 126, 14843; (f) T. Fukaminato, J. Photochem. Photobiol. C, 2011, 12, 177-208; (f) J. X. Liu, B. Xin, C. Li, N.-H. Xie, W.L. Gong, Z.-L. Huang, M.-Q. Zhu, ACS Appl. Mater. Interfaces, 2017, 9, 10338-10343.

[6] (a) V. Guerchais, J. Boixel, H. Le Bozec, In Photon-Working Switches, (Eds. Y. Yokoyama, K.;Nakatani) Springer Japan, 2017, Chapter 18; (b) V. Guerchais, L. Ordronneau, H. Le Bozec, Coord. Chem. Rev. 2010, 254, 2533-2545.

[7] (a) A. J. Kronemeijer, H. B. Akkerman, T. Kudernac, B. J. van Wees, B L. Feringa, P. W. M. Blom, B. de Boer, Adv. Mater. 2008, 20, 1467-1473 (b) S. J. van der Molen, J. Liao, T. Kudernac, J. S. Agustsson, L. Bernard, M. Calame, B. J. van Wees, B. L. Feringa, C. Schönenberger, Nano Lett 2009, 9, 76-80; (c) F. Meng, Y.-M. Hervault, L. Norel, K. Costuas, C. Van Dyck, V. Geskin, J. Cornil, H. Hoon Hng, S. Rigaut, X. Chen, Chem. Sci. 2012, 3, 3113-3118; (d) C. Jia, A. Migliore, N. Xin, S. Huang, J. Wang Q. Yang, S. Wang, H. Chen, D. Wang, B. Feng, Z. Liu, G. Zhang, D.-H. Qu, H. Tian, M.-A. Ratner, H.-Q. Xu, A. Nitzan, X. Guo, Science, 2016 352, 1443-1445

[8] (a) J. J. D. de Jong, L. N. Lucas, R. M. Kellogg, J. H. van Esch, B. L. Feringa, Science, 2004, 304, 278-281; (b) J. T. Van Herpt, M. C. A. Stuart, W. R. Browne, B. L. Feringa, Chem. Eur. J. 2014, 20, 3077-3083.

[9] (a) U. Al-Atar, R. Fernandes, B. Johnsen, D. Baillie, N. R. Branda, J. Am. Chem. Soc. 2009, 131, 15966-15967; (b) O. Yehezkeli, M. Moshe, R Tel-Vered, Y. Feng, Y. Li, H. Tian ,I. Willner, Analyst, 2010, 135, 474 476.

[10] T. Leydecker, M. Herder, E. Pavlica, G. Bratina, S. Hecht, E. Orgiu, P. Samorì, Nat. Nanotech., 2016, 11, 769-775.

[11] Two DTEs linked by a silyl spacer: J. Areephong, W. R. Browne, B. L. Feringa, Org. Biomol. Chem. 2007, 5, 1170-1174.

[12] C. Li, H. Yan, L.-X. Zhao, G.-F. Zhang, Z. Hu, Z.-L. Huang, M.-Q. Zhu, Nat. Commun. 2014, 5, 5709 .

[13] J. Areephong, H. Logtenberg, W. R. Browne, B. L. Feringa, Org. Lett 2010, 12, 2132-2135.

[14] Arenyl spacers: H. Choi, H. Jung, K. H. Song, D.-S. Shin, S. O. Kang, J Ko, Tetrahedron, 2006, 62, 9059-9065.

[15] (a) A. Fihey, A. Perrier, W. R. Browne, D. Jacquemin, Chem. Soc. Rev. 2015, 44, 3719-3759; (b) A.Perrier, F. Maurel, D. Jacquemin, Acc. Chem Res. 2012, 45, 1173-1182; (c) D. Bleger, J. Dokic, M. V. Peters, L. Grubert, P. Saalfrank, S. Hecht, J. Phys. Chem. B, 2011, 115, 99309940; (d) F. Cisnetti, R. Ballardini, A. Credi, M. T. Gandolfi, S. Masiero, F. Negri, S. Pieraccini, G. P. Spada, Chem. Eur. J. 2004, 10, 2011-2021.

[16] H. Tian, B. Chen, H. Tu, K. Müllen, Adv. Mater. 2002, 14, 918-923.

[17] DTEs bridged by an alkynyl spacer: T. Kaieda, S. Kobatake, H Miyasaka, M. Murakami, N. Iwai, Y. Nagate, A. Itaya, M. Irie, J. Am. Chem. Soc., 2002, 124, 2015-2014.

[18] Alkyl spacers: (a) A. Peter, N. R. Branda, Adv. Mater. Opt. Electron. 2000, 10, 245-249; (b) T. Kaieda, S. Kabatake, H. Miyasaka, M Marukami, N. Iwai, Y. Nagata, A. Itaya, M. Irie, J. Am. Chem. Soc. 2002 124, 2015-2024.

[19] Alkynyl spacer: K. Yagi, M. Irie, Chem. Lett. 2003, 32, 848-849.

[20] Arenyl spacers: T. Kawai, T. Sasaki, M. Irie, Chem. Commun., 2001 711-712.

[21] DTEs arranged around metal complexes: (a) E. C. Harvey, B. L. Feringa J. G. Vos, W. R. Browne, M. T. Pryce, Coord. Chem. Rev. 2015, 282, 77 86; (b) L. Ordronneau, V. Aubert, V. Guerchais, A. Boucekkine, H. Le Bozec, A. Singh, I. Ledoux, D. Jacquemin, Chem. Eur. J., 2013, 19, 5845-5849.

[22] (a) D. R. Reddy, B. G. Maiya, Chem. Commun. 2001, 117-118; (b) D. R Reddy, B. G. Maiya, J. Phys. Chem. A, 2003, 107, 6326-6333; (c) M. V. Peters, R. Goddard, S. Hecht, J. Org. Chem. 2006, 71, 7846-7849.

[23] C. A. Hunter, L. D. Sarson, Tetrahedron Lett. 1996, 37, 699-702. 
[24] H. J. Kim, J. H. Jang, H. Choi, T. Lee, J. Ko, M. Yoon, H.-J. Kim, Inorg Chem. 2008, 47, 2411-2415.

[25] J. Frey, G. Kodis, S. D. Straight, T. A. Moore, A. L. Moore, D. Gust, J Phys. Chem. A, 2013, 117, 607-615.

[26] P. A. Liddell, G. Kodis, A. L. Moore, T. A. Moore, D. Gust, J. Am. Chem. Soc. 2002, 124, 7668-7669.

[27] D. E. Williams, J. A. Rietman, J. M. Maier, R. Tan, A. B. Greytak, M. D. Smith, J. A. Krause, N. B. Shustova, J. Am. Chem. Soc. 2014, 136 11886-11889.

[28] L. Hou, X. Zhang, T. C. Pijper, W. R. Browne, B. L. Feringa, J. Am. Chem. Soc. 2014, 136, 910-913.

[29] O. Nevskyi, D. Sysoiev, A. Oppermann, T. Huhn, D. Woll, Angew. Chem. Int. Ed. 2016, 55, 12698-12702.

[30] B. Roubinet, M. L. Bossi, P. Alt, M. Leutenegger, H. Shojaei, S. Schnorrenberg, S.; Nizamov, M. Irie, V. N. Belov and S. W. Hell, Angew. Chem. Int. Ed. 2016, 55, 15429-15433.

[31] B. Roubinet, M. Weber, H. Shojaei, M. Bates, M. L. Bossi, V. N. Belov, M. Irie, S. W. Hell, J. Am. Chem. Soc. 2017, 139, 6611-6620.

[32] (a) T. B. Norsten, N. R Branda, J. Am. Chem. Soc., 2001, 123, 1784 1785; (b) J. Kärnbratt, M. Hammarson, S. Li, H. L. Anderson, B. Albinsson, J. Andréasson, Angew. Chem. Int. Ed. 2010, 49, 1854-1857 (c) T. B. Norsten, N. R. Branda, Adv. Mater. 2001, 13, 347-349.

[33] A. Osuka, D. Fujikane, H. Shinmori, S. Kobatake and M. Irie, J. Org Chem. 2001, 66, 3913-3923.
[34] S. D. Straight, P. A. Liddell, Y. Terazono, T. A. Moore, A. L. Moore, D. Gust, Adv. Funct. Mater. 2007, 17, 777-785

[35] (a) J. S. Lindsey, H. C. Hsu and I. C. Schreiman, Tetrahedron Lett. 1986 27, 4969-4970; (b) J. S. Lindsey, I. C. Schreiman, H. C. Hsu, P. C. Kearney, A. M. Marguerettaz, J. Org. Chem. 1987, 52, 827-836.

[36] S. Yamamoto, K. Matsuda, M. Irie, Angew. Chem. Int. Ed. 2003, 42, 1636-1639.

[37] S. Pu, L. Hui, L. Gang, L. Weijun, C. Shiqiang, F. Congbin, Tetrahedron, 2011, 67, 1438-1447.

[38] E. G. Azenha, A. C. Serra, M. Pineiro, M. M. Pereira, J. Seixas de Melo, L. G. Arnaut, S. J. Fromosinho, A. M. d'A. Rocha Gonsalves, Chem. Phys. 2002, 280, 177-190.

[39] A. J. Myles, N. R. Branda, Tetrahedron Lett. 2000, 41, 3785-3788.

[40] M. Pineiro, A. L. Carvalho, M. M. Pereira, A. M. Rocha Gonsalves, L. G Arnaut, S. Formosinho, J. Chem. Eur. J., 1998, 4, 2299-2307.

[41] J. S. Baskin, H.-Z. Yu and A. H. Zewail, J. Phys. Chem. A 2002, 106, 9837-9844.

[42] H.-Z. Yu, J. S. Baskin and A. H. Zewail, J. Phys. Chem. A 2002, 106, 9845-9854.

[43] In the experimental set-up used, emission on thin films was measured with a standard right-angle excitation optical scheme. Conversely, to perform quantitative measurements, the use of an integrating sphere would be necessary. See also: H. Ishida, J.-C. Bünzli, A. Beeby, Pure Appl. Chem. 2016, 88, 701-711, 
Think pink ink. Multiple switching events of dithienylethenes around a porphyrin core provide highly contrasted fluorescence readout and photo-rewritable fluorescent inks.

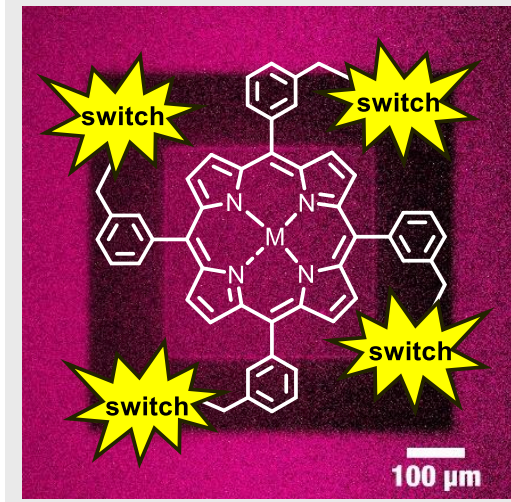

T. Biellmann, A.Galanti, J. Boixel J. A. Wytko, V. Guerchais, ${ }^{*} P$. Samori* and Jean Weiss *

Page No. - Page No.

Fluorescence commutation and surface photopatterning with porphyrin tetra-dithienylethene switches 